\title{
Clean Water for La Ceiba, El Salvador - Household Biosand Filters
}

\author{
Kelly Barb \\ Civil \& Environmental Engineering \\ Rowan University \\ Glassboro, NJ 08028 \\ kelly.a.barb@gmail.com>
}

\author{
Jess W. Everett \\ Professor of Civil \& Environmental Engineering \\ Rowan University \\ Glassboro, NJ 08028 \\ everett@rowan.edu
}

\begin{abstract}
Engineers Without Borders (EWB) at Rowan University is a student-led organization that combines skills learned in the university classroom with real world experience, channeling the passion and knowledge of students to partner with communities in developing nations to solve engineering problems. In doing so, students learn civic responsibility, heighten their social awareness, and become actively contributing citizens of communities in both the United States and around the world. Students also learn skills that apply to the workplace, including project and team management, planning and organization, communication, fundraising and budgets, engineering "on the ground," and knowledge transfer. The Rowan EWB chapter partnered with the residents of La Ceiba, El Salvador to construct household biosand filters to achieve the ultimate goal of providing potable drinking water for the community. The purpose of this paper is threefold: (1) describe the Rowan Engineering Clinic course sequence, used to prepare and award credit to students working on EWB projects; (2) describe the La Ceiba project, focusing on the process used to identify and implement the ultimate solution; and (3) provide information on the household biosand filters that could be useful to other service organizations. As of January 2013, 54 filters have been installed. The filter recipients are satisfied and able to maintain their filters, with a notable self-reported decrease in water-related illness. Some filters cracked, and even leaked, but the local concrete vendor worked with residents to make repairs. Iterations in the filter box design have reduced the cracking problem. Community residents are maintaining their own filters.
\end{abstract}

Index Terms - El Salvador, EWB, sustainable engineering, water, biosand filter

\section{INTRODUCTION}

The Rowan University student chapter of Engineers Without Borders was established in 2003 and has worked on projects in The Gambia, Senegal, South Dakota, El Salvador, Thailand, and Honduras. It operates under the guidance and regulation of the national organization. Engineers Without Borders USA (EWB-USA) was started in 2002. ${ }^{1}$ It was the brainchild of Angel Tzec, a landscaper and representative of the Belize Ministry of Agriculture, and Bernard Amadei, a Professor of Civil Engineering at the University of Colorado at Boulder. EWB-USA has grown from eight engineering students and one professor to an organization of student and professional chapters, with over 12,000 student, faculty and professional members. EWB-USA chapters 
provide engineering expertise to address community-identified infrastructure needs. The focus is on sustainable solutions for communities in need.

The Rowan EWB chapter partnered with the residents of La Ceiba, El Salvador to construct household biosand filters to achieve the goal of providing potable drinking water to the community. The purpose of this paper is threefold:

1. Describe the Rowan Engineering Clinic course sequence, used to prepare and award credit to students working on EWB projects;

2. Describe the La Ceiba project, focusing on the process used to identify and implement the ultimate solution; and

3. Discuss problems with the household biosand filters.

The intention is to help others address the wide variety of issues affecting EWB chapters.

\section{Rowan EngineERing CliniC}

The Engineering Clinic program at Rowan University is an 8-semester sequence of hands-on courses that culminates with multidisciplinary teams of juniors and seniors working on realworld projects. ${ }^{2}$ The Freshman Clinic series is focused on engineering measurements and reverse engineering. The Sophomore Clinic series is focused on engineering design and communication, with one semester focused on technical writing and one on public speaking. By the time they are juniors, engineering students at Rowan University are prepared to complete certain real-world engineering projects under the supervision of a professor. Most Junior and Senior Clinics have an external sponsor and funding. This was true of the EWB "Clean Water for La Ceiba" project, with students working with community residents, submitting reports to EWB-USA, and applying to numerous sources to obtain funding.

The EWB engineering clinic is taught and advised by Rowan University EWB chapter faculty. A number of deliverables are used to structure the course. Each new student to the EWB clinic team familiarizes themselves with background material required to understand the project. For EWB clinics, this is the previous teams' reports. The new student submits a "new student" memo to demonstrate their familiarity with the project. The team submits a schedule of tasks they will complete to meet each semester's goal and objectives. When experiments are conducted as part of the EWB clinic, the team submits laboratory reports following formats learned in freshman and sophomore clinic. The Clinic team submits funding proposals to various organizations.

All EWB-USA reports are also submitted as course deliverables. Reports are graded on spelling \& grammar, format, and content. Typically, draft EWB-USA reports are submitted at least a week before they are due at EWB-USA. This gives faculty reviewers enough time to provide comments so the students can improve the report as needed before submitting it to EWB-USA. A number of the chapter's reports have been used by EWB-USA as examples of superior work. When EWB clinic team members travel, they submit a reflections memo to describe their take-away from the trip.

Each semester, the EWB clinic team gives midterm \& final presentations, following formats learned in Freshman and Sophomore clinic. Team members often given additional presentations to groups interesting in supporting the projects, e.g., Rotary, Engineering societies, etc. Each 
student submits an accomplishments memo at the end of the semester. They use the memo to justify a particular course letter grade. Each student also submits a peer evaluation of each team member.

The EWB Clinic students meet at least twice a week, three hours each time, during the academic year. Students work additional hours as needed. The EWB chapter meets twice a month during the academic year, and completes workshops and service projects to build skill sets with the membership. Travel teams are made up of chapter members in and out of the EWB clinic. Students only receive college credit for their EWB activities if they become a part of an EWB Junior/Senior Engineering Clinic. The result of the combined action of the EWB clinic team(s) and the EWB chapter have been excellent. The EWB chapter has made good progress on its EWB projects.

\section{Project Development}

The typical EWB project requires assessment and design phases before implementation. This was the case for the La Ceiba project.

\section{Assessment Phase}

A Peace Corps volunteer submitted an application with the residents of La Ceiba to EWB-USA based on concerns that the community's water sources were causing illness and death, especially among the children in the community. La Ceiba is home to approximately 800 people, with roughly 150 households, three churches, four family stores, a soccer field and a four-classroom school. It is located approximately 10 kilometers from the El Salvador - Guatemala border and 14 kilometers from the Pacific Ocean (Figure 1). The majority of the population relies on remittances sent back from family members in the United States for income, as the average salary for workers in the area ranges from $\$ 5$ to $\$ 7$ a day. The main occupation of the area is farming, with major crops being sugar cane, coffee, and corn.

In early 2007 the Rowan EWB student chapter adopted the project and went on its first assessment trip. A survey of the community revealed that there were high occurrences of diarrhea, bloated stomachs, infections, and infant mortality. Children comprise approximately $48 \%$ of the population in La Ceiba, and as many as 34 children died between 2002 and 2007 as a result of lack of clean water. Children in La Ceiba were dying at a rate much higher than the average infant mortality rate in El Salvador, 21.52 deaths per 1000 live births. ${ }^{3}$ 


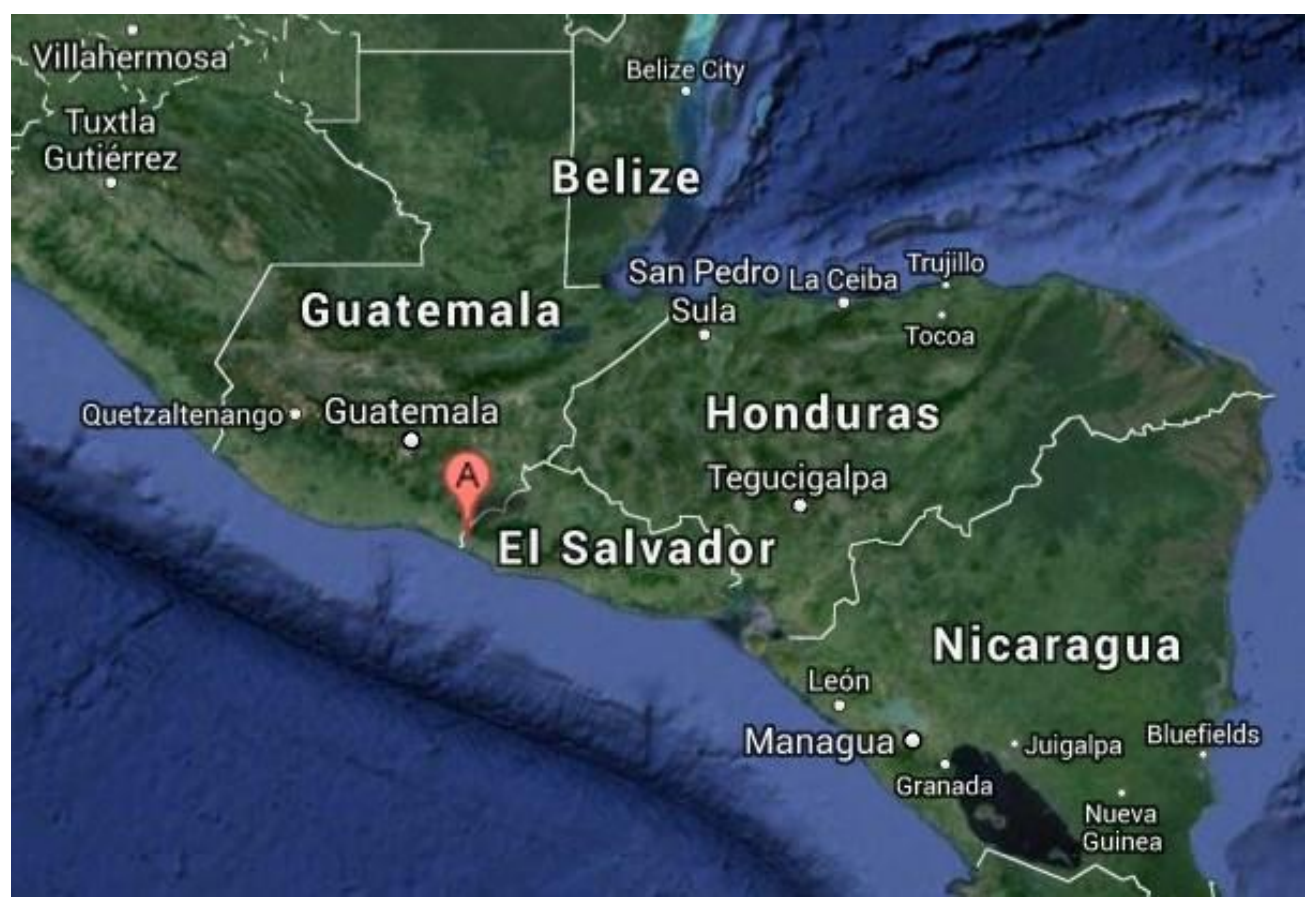

FIGURE 1

LA CEIBA, El SALVADOR ${ }^{4}$

There are two sources of water in La Ceiba. Most homes have shallow, hand-dug wells in their yards or houses that provide water for all household functions: cooking, bathing, drinking, and washing. Wells are unlined except for the top few feet $(1-2 \mathrm{~m})$. A typical well is shown in Figure 2. These wells are contaminated by animal and human waste disposed of improperly or in nearby latrines. Contamination occurs via groundwater or surface water runoff during the wet season. There is also a small river that runs through the town, which provides water for drinking and cooking for families without wells. It is also a location for dumping trash, taking baths, washing dishes and clothing, and watering cattle. Samples of river and well water collected by the assessment team tested positive for fecal coliform. 


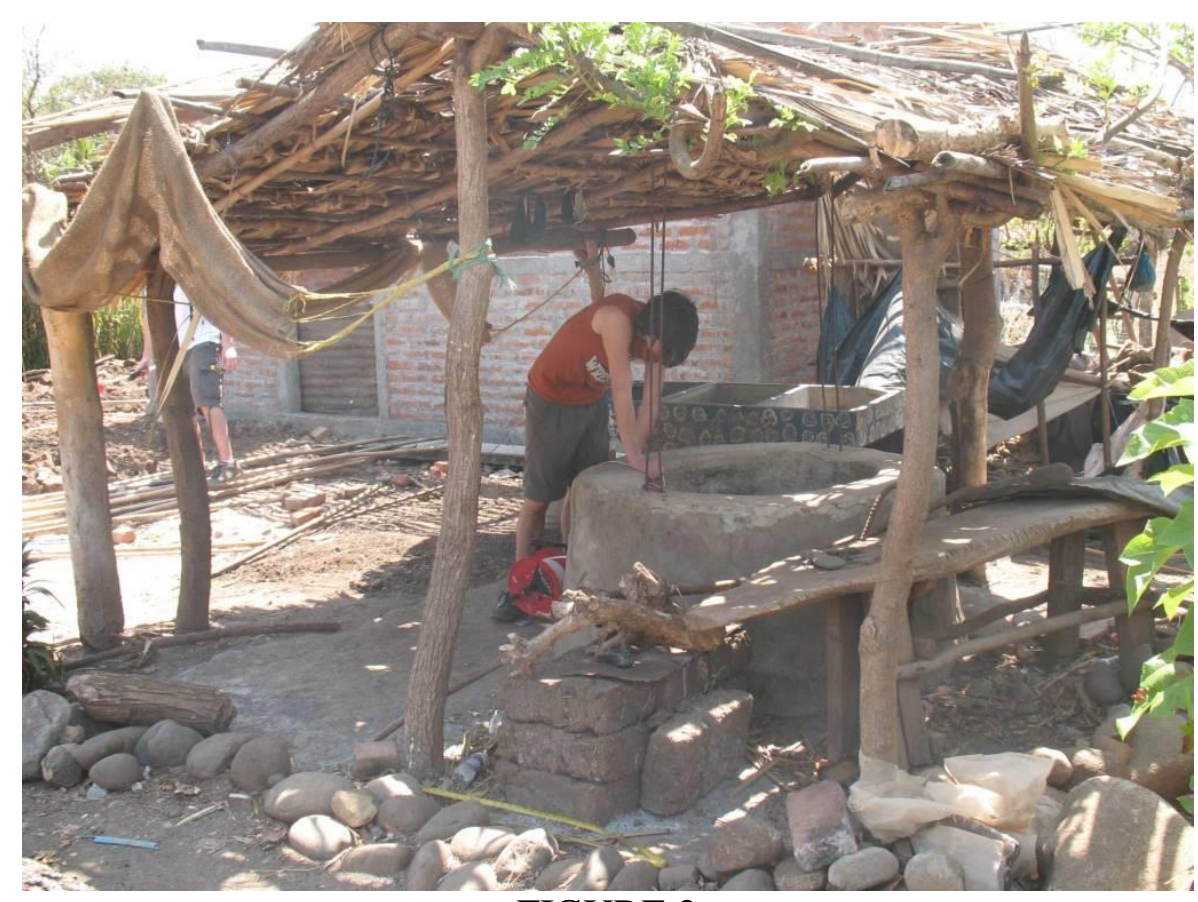

FIGURE 2

A STUDENT MEASURES THE DEPTH OF A TYPICAL LA CEIBA WELL

The Peace Corp volunteer finished her assignment shortly after the first assessment trip. While Peace Corp volunteers are an excellent resource for identifying communities in need, they often end their appointment shortly after attracting a EWB chapter to their community. This can leave the EWB chapter without a local contact or organization to provide logistical support. Projects with communities and committed NGOs are often much easier to complete. The La Ceiba project depended entirely on the resources of community members.

Fortunately, a local health worker was willing to serve as the chapter's contact in the community. Dominga is a non-government employee with Agape. She has lived in La Ceiba for years and does health promotion and basic clinic work. She coordinated housing and meals for the EWB travel team, and was a point of contact throughout the year when the team was not incountry.

After the first assessment trip in May 2007, many water supply alternatives were investigated and evaluated based on the quality and quantity of the water provided, the cost of the solution, how many people would be required to maintain the solution, and how satisfied the community would be with the solution. Household-scale biosand filtration and a community distribution system were selected as the best options. In completing an Alternatives Analysis, which was required by EWB-USA, students had to synthesize the pros and cons of all possible design options. Table 1 is used to provide a summary of the team's Alternatives Analysis Report. ${ }^{5}$

A second assessment trip was conducted in May of 2008 to present the two possible solutions to the community, educate the community about safe drinking water, and collect data needed to finish designing the solution selected by the community. When presented with the two possible solutions, the townspeople understandably selected the distribution system with 15 community spigots. Surveys showed that each household was willing to pay around $\$ 2.00$ per month for water. 
TABLE I

ROWAN UNIVERSITY ALTERNATIVES ANALYSIS

\begin{tabular}{|c|c|c|}
\hline Alternative & Pros & Cons \\
\hline $\begin{array}{l}\text { Education on } \\
\text { Puriagua* }\end{array}$ & Community able to treat water & Chlorine taste \\
\hline Extra Jugs & Encourages use of Puriagua & Does not provide clean water \\
\hline Slow Sand Filter & Clean water for entire town & May be very expensive \\
\hline $\begin{array}{l}\text { Ceramic Pot } \\
\text { Filtration }\end{array}$ & Treats water & Filtration is slow \\
\hline Solar Disinfection & $\begin{array}{l}\text { Simple, inexpensive way to } \\
\text { treat water }\end{array}$ & $\begin{array}{l}\text { Only removes a small percentage of } \\
\text { contamination }\end{array}$ \\
\hline $\begin{array}{l}\text { Moringa Seed } \\
\text { Treatment }\end{array}$ & Removes turbidity & $\begin{array}{l}\text { Does not remove biological } \\
\text { contamination }\end{array}$ \\
\hline Latrine System & Reduce contamination of wells & $\begin{array}{l}\text { May not completely eliminate } \\
\text { contamination of wells }\end{array}$ \\
\hline New Wells & Source of clean water & Too expensive \\
\hline $\begin{array}{l}\text { Renovate Existing } \\
\text { Wells }\end{array}$ & Inexpensive & May not stop contamination \\
\hline Distribution System & Clean water for entire town & $\begin{array}{l}\text { Need water source that can be accessed } \\
\text { affordably }\end{array}$ \\
\hline
\end{tabular}

*Puriagua is a disinfectant supplied by the government

After the second assessment trip, the EWB chapter decided to collaborate with the Drexel University chapter, which was working on a water distribution system in the nearby town of Miramar. Since the two towns were in need of potable water, it was thought that it would be more efficient to partner and focus on one water source for both towns.

A hydrogeologic survey was commissioned to determine the best location for a well and the type of well that would be required to provide the towns with a sufficient supply of potable water. The survey reported that the well would have to be 17.375 inches in diameter and 460 feet deep. It was determined that drilling a well of this size was not economically feasible for the Rowan University EB chapter and that the people of La Ceiba would find it difficult to pay the operating expenses of the well's pump. A quote from a local well driller put the estimated cost for drilling the well at $\$ 30,000$. A quote from a local pump supplier put the estimated cost for 
purchasing and installing the pump at $\$ 20,000$. This did not include the cost of storage tanks, pipe, or spigots, which would cost an additional $\$ 20,000$. The estimated costs of operating the distribution system--electricity for operating the pump, disinfectant supplies, and labor--were approximately $\$ 9.00$ per household per month. This cost would be reduced by the government subsidy of electricity, but the amount of the subsidy changes over time.

Surveys were sent to each household to explain the findings and get the community's input on how to move forward with the project. When asked about the operation and maintenance costs for the system, almost every household responded that they could not afford to pay $\$ 9.00$ a month for water. Almost every household also reported that they would use a biosand filter if the chapter helped to provide it.

The EWB chapter continued looking into alternative sources of water for the community. The alternative sources included infiltration galleries, rainwater catchment, and surface water treatment. Research was also conducted to determine what would be required to build biosand filters with the community.

In the months leading up to traveling a third time, the clinic team and student chapter worked diligently to research water purification and filter designs, write grants and host fundraisers, and develop a plan for the future of this project, all of this in addition to schoolwork and other commitments.

The chapter went on a third assessment trip to further investigate these possible solutions. During the trip team members met with the community, discussed the project, collected surveys from each household, signed an MOU with a recently created La Ceiba water committee, and discussed payment options. Team members researched the prices and availability of materials that would be needed to build biosand filters in La Ceiba. They identified a local concrete vendor who was able and willing to form the concrete boxes for the Biosand filters. Water quality tests were conducted on river and well water, and water treated by a small number of biosand filters already operating in La Ceiba, supplied by a former NGO in the community.

Due to the rocky terrain in La Ceiba, the travel team decided that building an infiltration gallery would be very difficult and expensive. The community was not enthusiastic about rainwater catchment because they felt that biosand filters would be a better solution. A surface water intake and a slow sand filter may have been feasible, but such a system was likely to be expensive and would take a long time to implement. All of the materials required to build biosand filters were locally available and the community was enthusiastic about building filters. Ultimately, the community met with the EWB team and decided to pursue the biosand filter option.

\section{Design Phase}

The La Ceiba biosand filter is based upon a design of the Centre for Affordable Water and Sanitation Technology. ${ }^{6}$ The filter is contained in a concrete box, about 3 feet $(0.9 \mathrm{~m})$ tall with walls of 1 inch $(2.54 \mathrm{~cm})$ thickness (Figure 3). Starting at the bottom, there is a layer of gravel that has been washed thoroughly, followed by a layer of coarse sand, and topped off with a layer of fine sand. There is a small ledge built into the box above the layer of fine sand on which a diffuser plate sits. This is a flat piece of metal or plastic with holes, acting as a strainer. When water is poured into the filter reservoir, the diffuser plate ensures that large contaminants do not pass and, more importantly, ensures that water flows through the filter uniformly, so as not to disturb the sand layer underneath and make it uneven. A PVC tubing system (not shown in Figure 3) within the concrete box runs from the base of the filter to the outlet. When water fills 
the biosand filter the pressure head drives water through the sand, into the PVC pipe, up to the outlet, and into a collection bucket for later use. A lid is kept on top of the filter, when water is not being poured in, to prevent contaminants from entering.

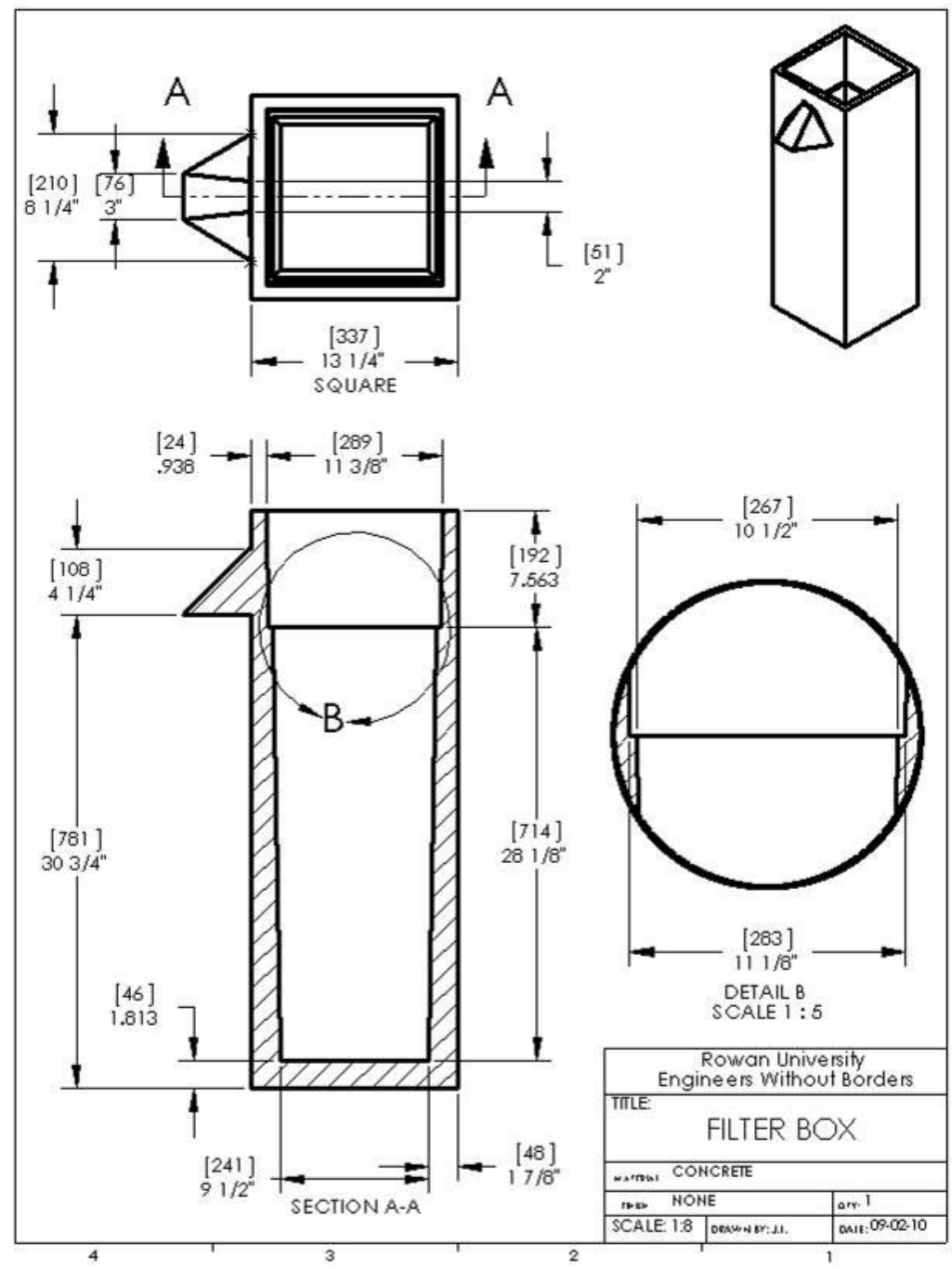

FIGURE 3

ROWAN UNIVERSITY BIOSAND FILTER DESIGN

A survey of La Ceibe residents determined that the average household used an average of 6.5 gallons of water each day for drinking and 8.5 gallons of water each day for cooking. The CAWST Version 10 biosand filter can be dosed with 12 liters, or 3.2 gallons, of water up to 4 times each day. ${ }^{7}$ Over the course of a day, a biosand filter of this size can treat up to 48 liters, or 12.7 gallons, of water. This is twice as much as the average household in La Ceiba drank each day, but a few gallons less than the total volume that the average household used for drinking and cooking combined. Subsequently, the La Ceiba filters are slightly larger than the CAWST Version 10 biosand filter, so they can to treat up to 57 liters (15 gallons) of water per day. ${ }^{8}$ 
The filter eliminates contamination in four ways:

- Adsorption, in which microbes or other suspended solids bind to the surface of sand particles and are removed from the water;

- Mechanical trapping, which occurs when microbes or other suspended solids get caught between the particles of sand and are removed from the water.

- Natural death of microbes within the confines of the filter; and

- Predation, or when microbes are consumed by other microbes.

A biological layer forms at the sand-water interface within 30 days of use if water is regularly poured into the filter. With the formation of the biological layer, the filter gains the ability to eliminate up to $99 \%$ of microbes. When the flow rate of the filter becomes too slow due to the buildup of contamination, the filter is cleaned by swirling the top layer of sand to break up the contamination and removing the dirty water. Upon cleaning, the biological layer can take up 30 days to reform.

Two prototypes were tested at Rowan University. First, the team looked into the possibility of converting a large plastic trash can into a filtration system, but the plastic could not withstand the weight of the sand. A second prototype was made based upon CAWST design, and was maintained in the laboratory for over a year. Using water from a nearby pond, which is actually too turbid to be filtered in a biosand filter according to CAWST standards, the filter still removed up to $99 \%$, sometimes $100 \%$ of fecal coliform and E. coli contamination. Design drawings for the second prototype were sent to the local concrete vender, who used them to make a mold. From 2010 to 2012, the vendor, EWB travel teams, and La Ceiba residents made 36 biosand filters based on the second prototype. Additional prototypes were constructed and evaluated incountry in 2012 to address cracking problems. Eighteen improved biosand filters were constructed in La Ceiba in January 2013 (Figure 4). Cracking issues are addressed later in this paper. 


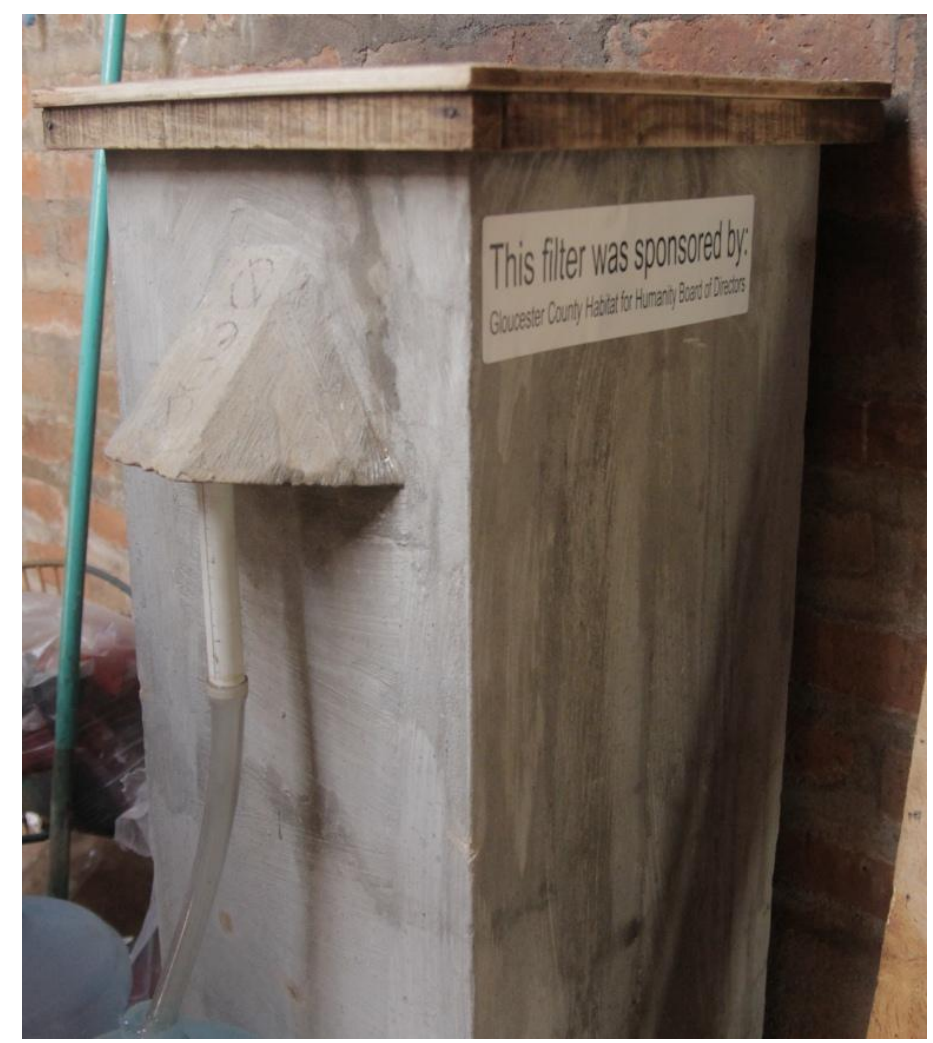

FIGURE 4

LATEST BiosAND Filter DeSign

\section{ProjeCt IMPLEMENTATION}

The cost to Rowan EWB for each filter is approximately $\$ 75$. As stated in the Memorandum of Understanding with the La Ceiba, the community commits to paying \$8 per filter and contribute to the labor needed to construct and install the components. The aim is to increase community involvement on each trip so that the community gains the skills and knowledge to implement filters on their own in the future. An "Adopt of Filter" program was successfully used to obtain donations. The filter shown in Figure 4 was adopted by the Gloucester County Habitat for Humanity Board of Directors.

A water committee, comprised of local leaders and concerned citizens from the community, was formed specifically for this project. The water committee was very responsive and active during the trip planning process. They met regularly and selected filter recipients and community members to participate in the construction and education process promptly when asked to do so. The water committee was successful in holding community-wide meetings. The water committee assisted the project team in arranging the purchase of tools and materials and checking up on the status of orders.

\section{Biosand Filter construction}

The biosand filter box construction process is described in a 525 Pre-Implementation Report. ${ }^{9}$ The report can be obtained from the first author. The material preparation process is described in the Appendix. Once the materials are prepared, the filter and materials are assembled in the 
recipient family's home. Figure 5 shows team members hand delivering a filter box to a family in La Ceiba. A filter needs: 1 gallon $(3.79 \mathrm{~L})$ of $1 / 4$ " large gravel, $1 / 2$ gallon $(1.89 \mathrm{~L})$ of $1 / 8$ " medium gravel, $1 / 2$ gallon $(1.89 \mathrm{~L})$ of $1 / 16$ " small gravel, and 10 gallons $(37.85 \mathrm{~L})$ of fine filtration sand. After adding the sand, the filter is flushed continuously until clear water leaves the outlet tube. The level of sand is then adjusted so that there is a 2-inch standing water level. Because local sources of sand were determined to contain arsenic (from natural sources), sand was obtained from approximately 2 hours away in El Salvador.

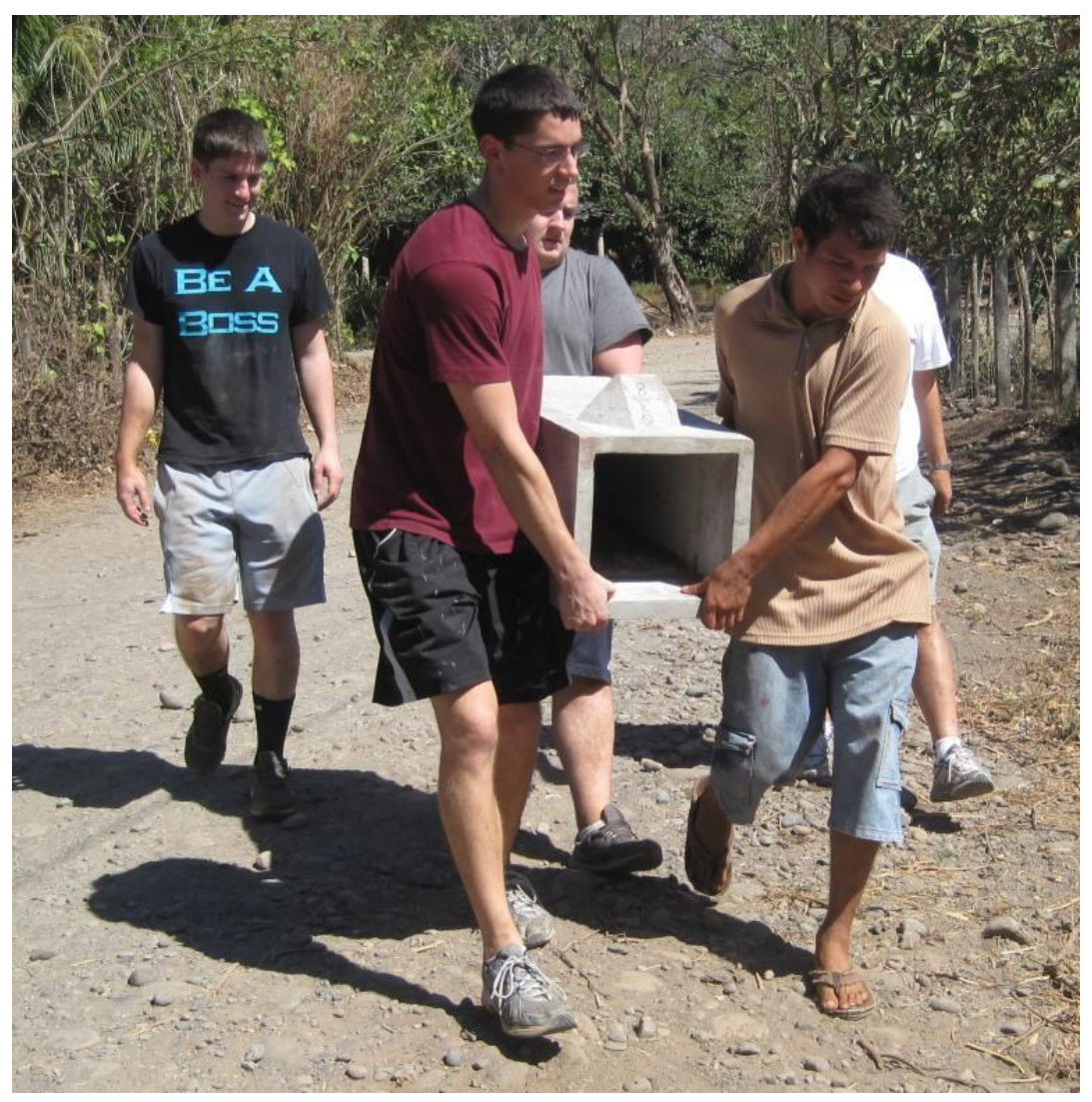

FIGURE 5

STUDENTS AND RESIDENTS DELIVER A FILTER BOX

After filters are flushed, they are disinfected to remove any contamination in the exit tube prior to use. This is done by pouring $5 \mathrm{~mL}$ of bleach into a $600 \mathrm{~mL}$ bottle and diluting it with water, then funneling the solution into the exit tube. Finally, the filter is flushed by pouring source water into the filter continuously until the water exits clear. After disinfection, the filter is ready to use, though maximum treatment is only achieved after the biological layer is established, which can take up to 30 days of continuous use.

Biosand filters were constructed during implementation trips in January 2011, June 2011, January 2012, and January 2013. A monitoring trip was taken in May 2012. As of January 2013, 54 filters had been installed in La Ceiba by the Rowan University EWB team. The tenth filter is shown in Figure 6. 


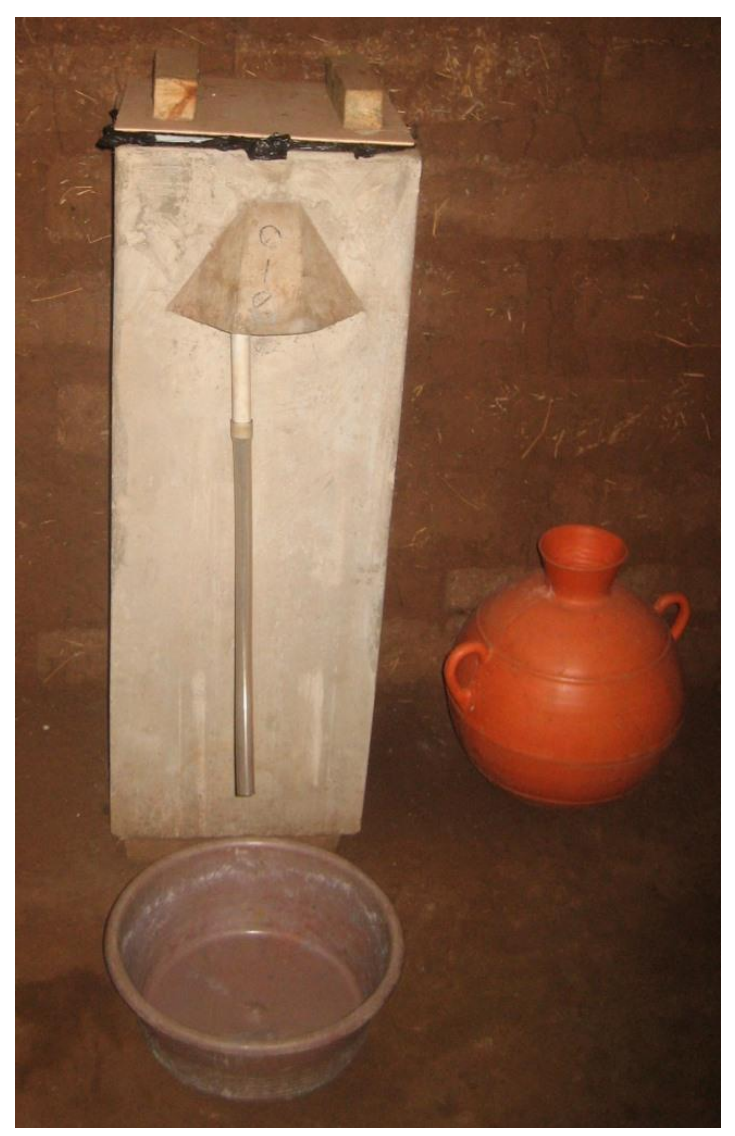

FIGURE 6

FILTER NUMBER 10

\section{La Ceiba School}

In addition to placing biosand filters in households, two filters were placed in the local school. La Ceiba has an elementary school that serves 200 children: 100 children in the morning session, and 100 children in the afternoon session. This school goes up to $6^{\text {th }}$ grade. In speaking with the director of the school, Miriam, it was found that children did not have clean water at school and were drinking from a contaminated well. In January 2012, the team installed a filter at the school. A second filter was installed in January 2013. One challenge with implementing the filter at the school is that the filter must have water added daily, and school is not in session on the weekends or holiday breaks. Neighbors of the school volunteered to maintain the filter when school was not in session. Miriam also expressed interest in incorporating filter education and health and sanitation education into the school's curriculum. Copies of educational materials were provided for them to do that.

\section{Education and Outreach}

Filter recipients must understand how their biosand filter works and how to maintain and troubleshoot it. Worksheets, card games, posters, and pamphlets, all translated into Spanish, were designed and printed to distribute to the community (See Appendix). The education team hosted classes for a representative from each church district, explaining the operation and maintenance of filters, as well as suggestions for general health and hygiene in the home and community. Filter recipients also received operation and maintenance training and educational pamphlets. 
Some people could not read, so all educational materials had to have pictures and diagrams to explain the writing in visual form. The team worked to improve educational materials with input from the community.

Another valuable method of outreach is town meetings. The team has held many in La Ceiba since 2007. Dominga coordinated town meetings, during which the community met with the team to discuss intentions for each trip, updates, and any concerns or questions that they have. A typical meeting is shown in Figure 7. On the most recent trip in January 2013 there were two community meetings. The first was to determine who would be receiving the 18 filters that were to be constructed. The second was to discuss the filter cracking issue present in previously installed filters.

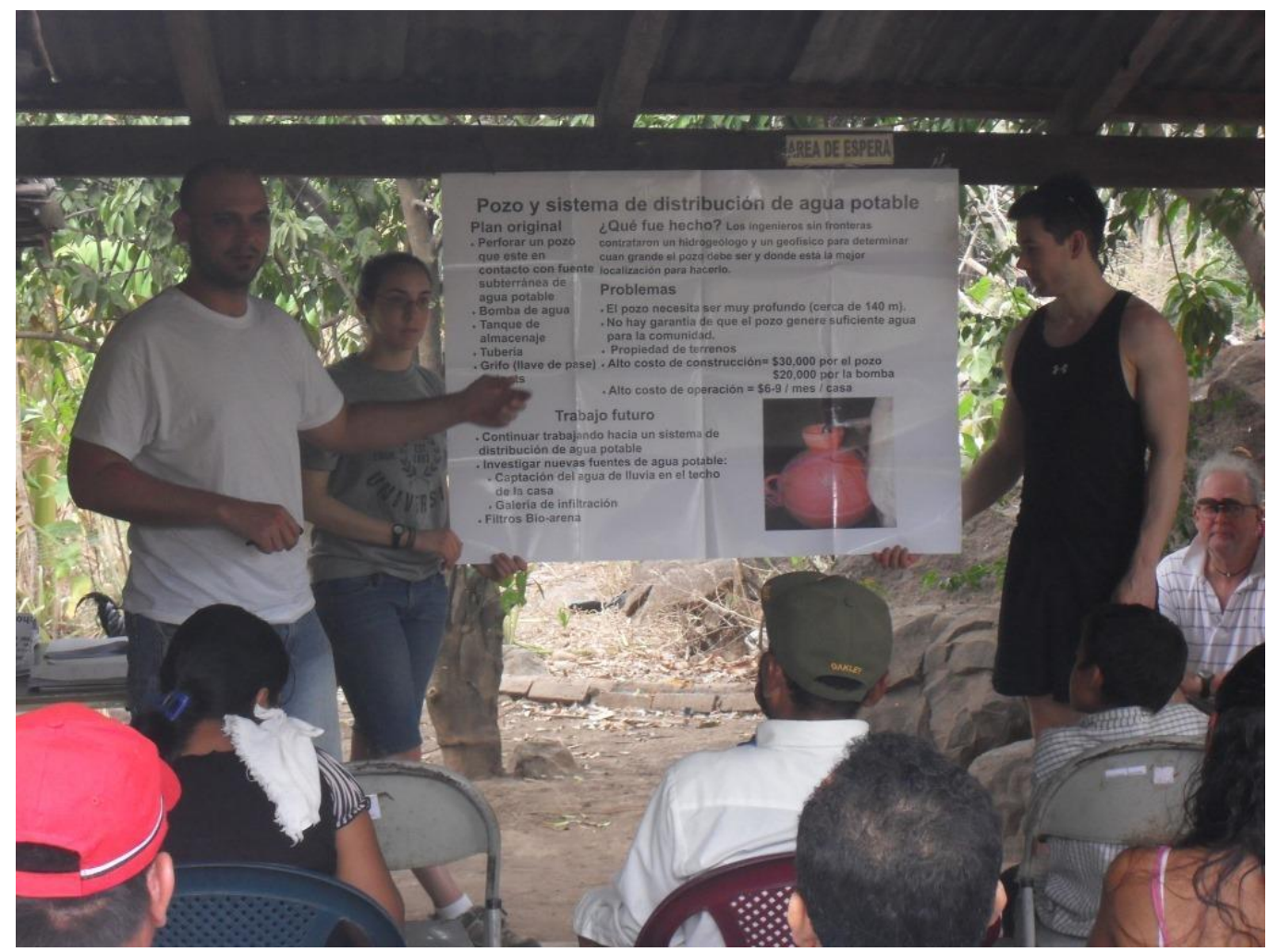

FIGURE 7

LA CEIBA TOWN MEETING

\section{Monitoring Phase}

Monitoring of previously installed filters took place during each implementation trip. One trip, in May 2012, was solely focused on monitoring. The results from this trip were reported in a 531 Post Monitoring Report. ${ }^{10}$ Monitoring was accomplished by surveying filter owners and observing/testing filters. Each family was interviewed and asked the same questions: when they last used their filter, how they clean their filter, when they last cleaned the filter, if it is functioning properly and if they have any questions or suggestions. The survey results indicate the filter recipients are satisfied and knowledgeable, with a notable self-reported decrease in water-related illness. 
A visual assessment was used to observe the condition of the filter. The team monitoring effort has shown that all filters are intact and in use. Some filters formed cracks, which were recorded with photos and on a worksheet. Cracks are discussed later in this paper.

The flow rate was measured and samples of source water and filtered water collected. These were tested for contamination. The team completed water quality testing to test for fecal coliform, E. coli, turbidity, arsenic, nitrate, nitrite, phosphate, $\mathrm{pH}$, total $\mathrm{Cl}$, free $\mathrm{Cl}$, hardness, alkalinity, and turbidity. Hach test strips were used to measure the levels of nitrate, nitrite, phosphate, hardness, alkalinity, $\mathrm{pH}$, total $\mathrm{Cl}$, and free $\mathrm{Cl}$. These parameters were all in acceptable ranges. A small sample of water was placed in a Hach turbidometer to determine turbidity. Water clarity was acceptable for all samples.

The Hach membrane filtration technique was used to determine fecal coliform and E. coli content. Briefly, $5 \mathrm{~mL}$ samples of river water and $10 \mathrm{~mL}$ samples of filtered water (diluted to 100 $\mathrm{mL}$ with bottled water) were passed through a membrane using a suction filtration technique, placed in a petri dish, and incubated for 24 hours. The colonies were counted after the incubation period, and a calculation for percent reduction from the well to the filter completed. Figure 8 shows MEF results for the river water, while Figure 9 shows MEF results for water treated by a biosand filter. As is evident from the Figures, the river water contained a large number of bacteria, which grew into visible colonies during the incubation period, while the biosand filter treated water did not.
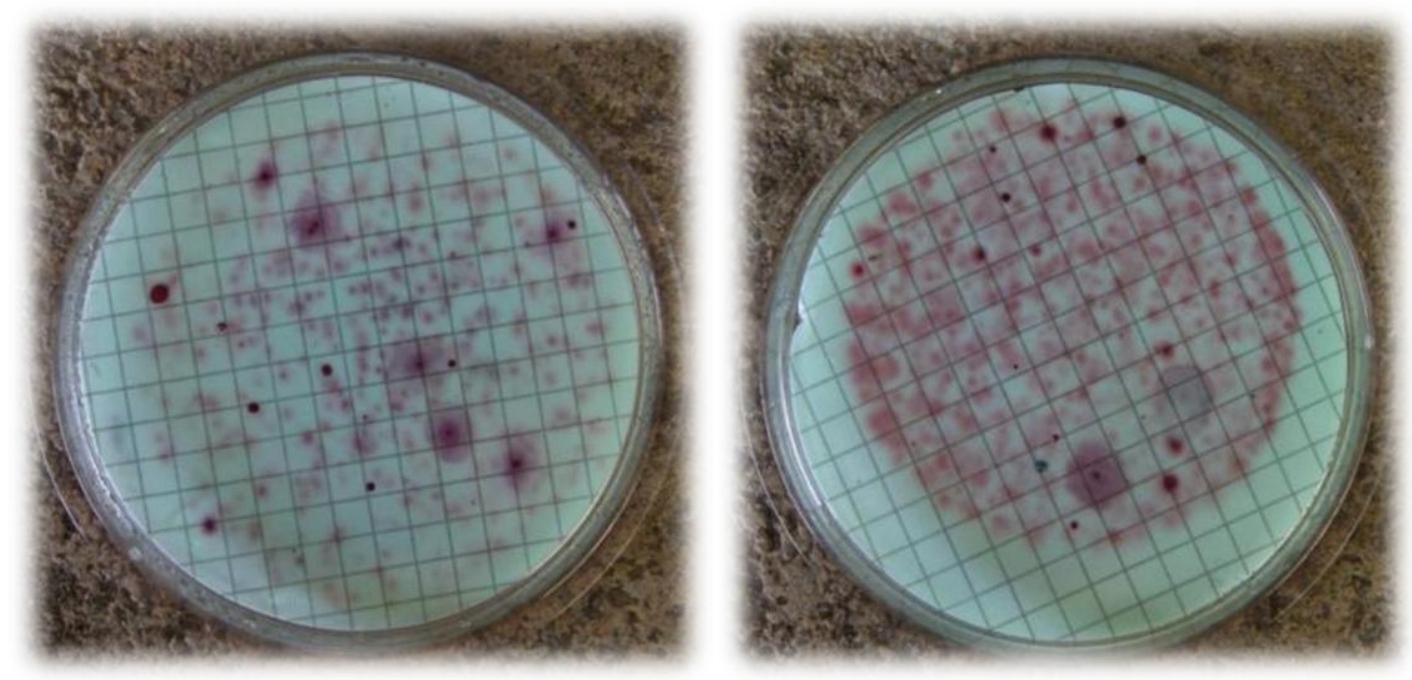

FIGURE 8

RIVER WATER SAMPLES 

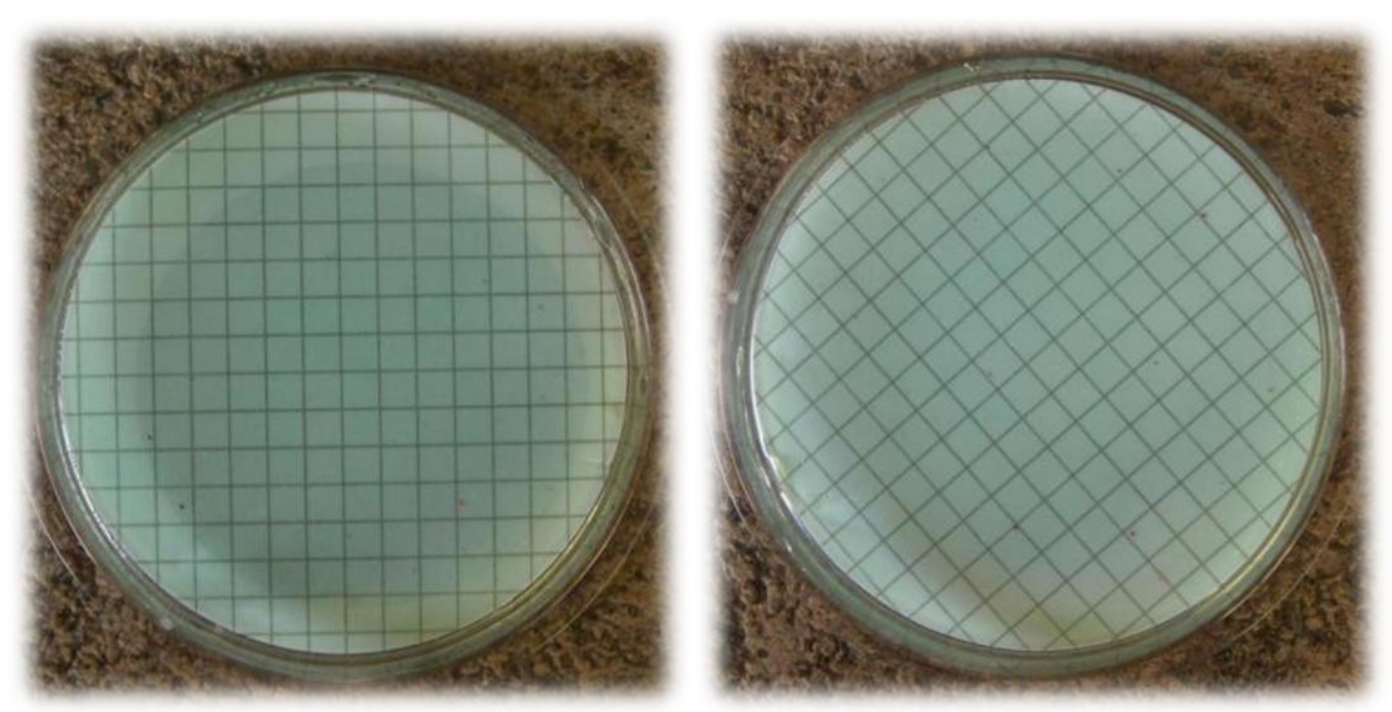

FIGURE 9

BIOSAND FILTER SAMPLES

Figure 10 is used to show results from January 2013 for fecal coliform testing of the 36 previously installed filters. These are the latest data available. The biosand filters ranged from 1 to 2 years old. Filters built and installed during the January 2013 trip were not tested as the biolayer was not yet formed. Results are unavailable for filters $9,15,30$, and 35 due to issues which arose during water quality field testing. Filter 4 was reinstalled during this trip, due to an ant infestation, so results were unavailable as well. Overall, there was a reduction in fecal coliform between the wells and the biosand filters. Some filters, including 8, 14, and 24, had a slightly higher fecal coliform count in the filter than the well. Since these wells were close to zero cfm, the team attributed these results to contamination in the sample preparation process. 


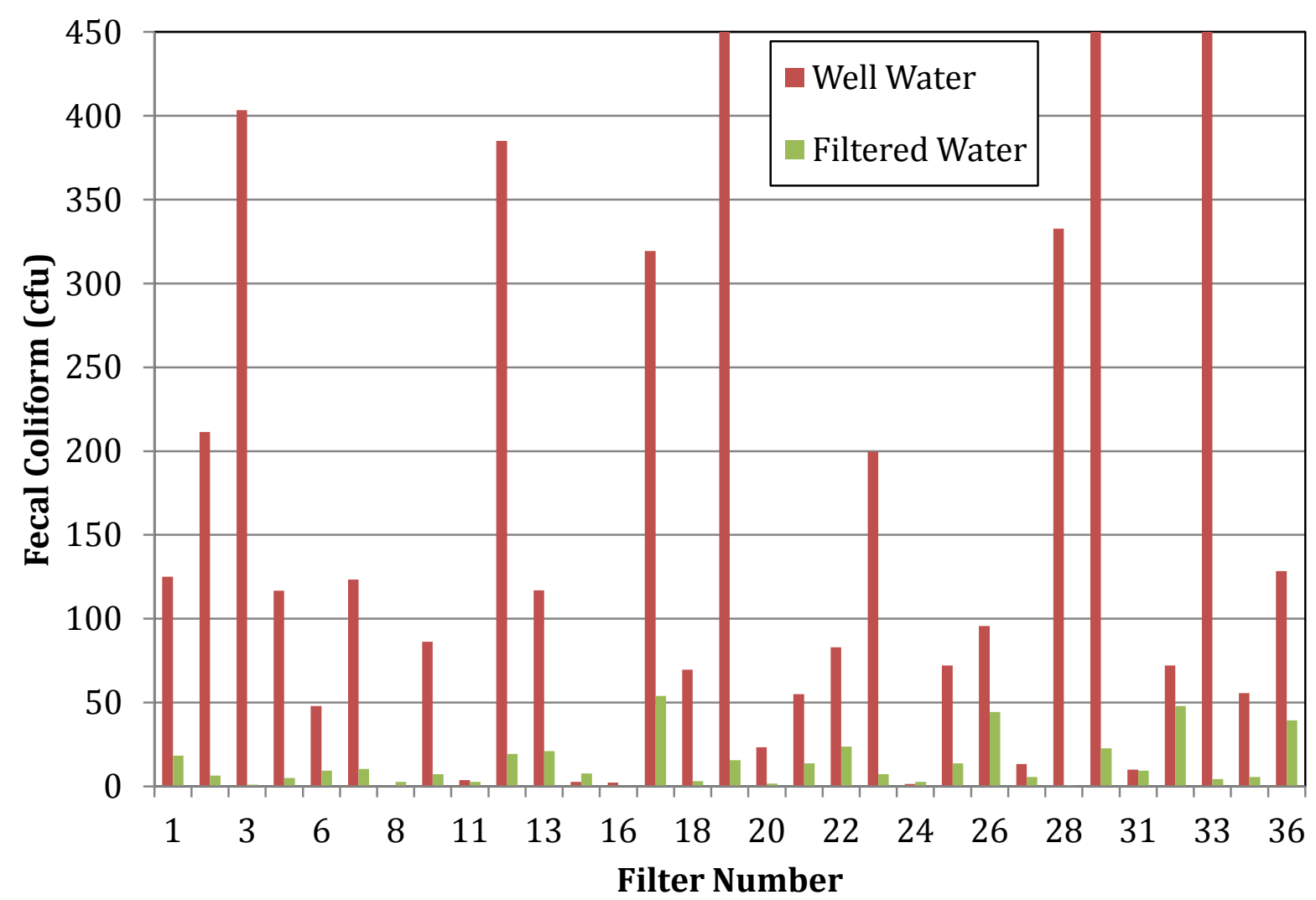

FIGURE 10

JANUARY 2013 FECAL COLIFORM REMOVAL DATA

(UNTREATED WELL WATER FOR FILTERS 19, 29, AND 33 HAD TOO MANY COLONIES TO COUNT)

\section{Project Setback - Cracking}

Some batches of filters exhibited characteristic cracking - a t-shaped crack on the front panel of the filter, cracks along the top (Figure 11), and/or hairline cracks at $1 / 3$ and $2 / 3$ down from the top of the filter. These fine cracks did not affect filter operator or result in leakage, but were of concern. Cracking can be attributed to several things. First, it could be the result of the fabrication process. Whether it is too much or too little of a component in the concrete mixture, not enough time in the mold, poor compaction, quality of materials used, improper storage (in sunlight, heat, humidity), transportation, placement of reinforcement and PVC piping, these are factors that the team can only describe to the concrete vendor and ask that he try to alleviate. Second, the cracking could be a result of the filter materials settling over time, with the sand in the inside of the filter constantly exerting forces on the concrete filter box. Finally, the thickness of the concrete walls or size and placement of steel reinforcing could be to blame. 


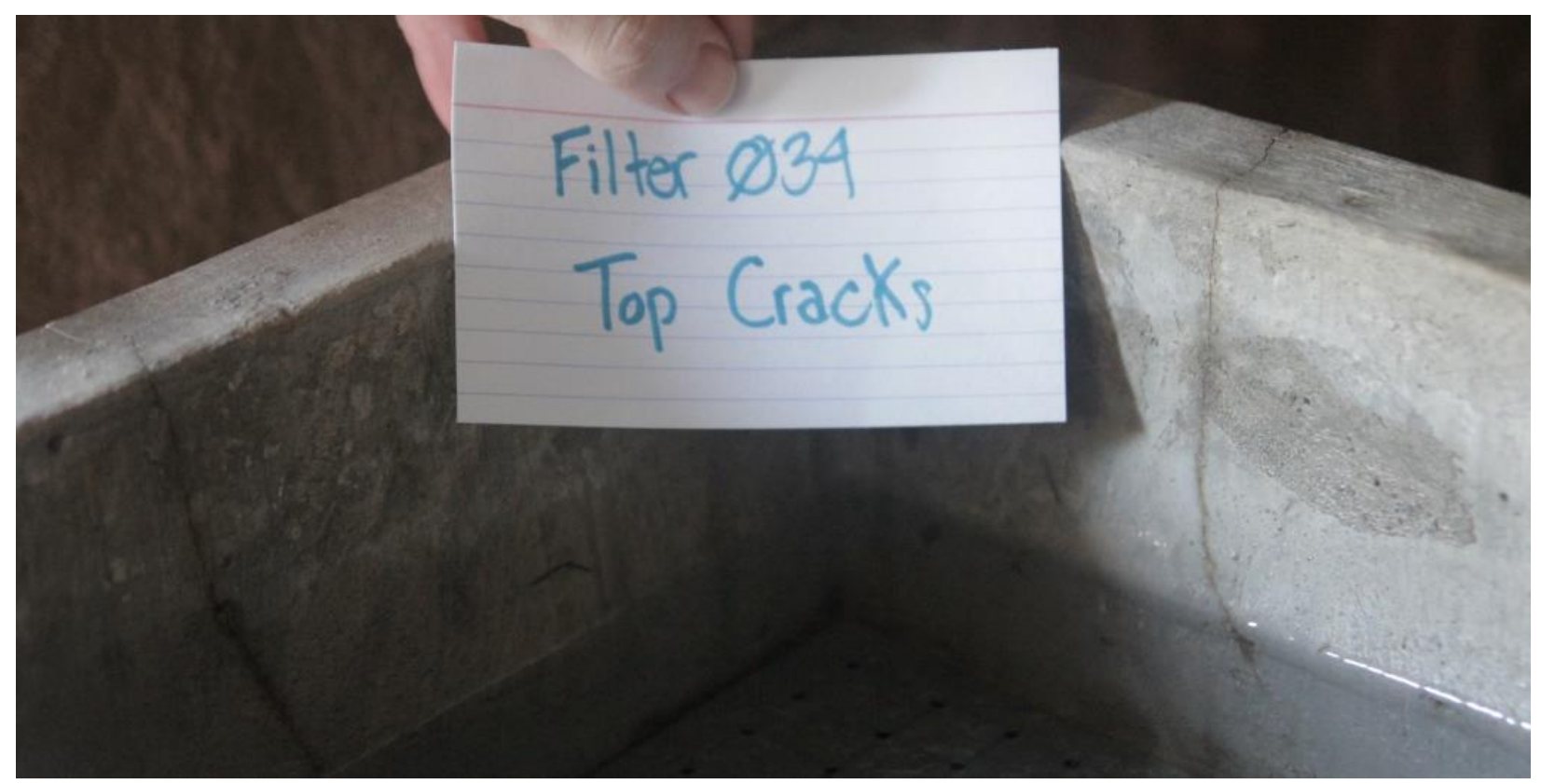

FIGURE 11

CRACKS IN TOP OF FILTER 34

The team worked with the concrete vendor to test new prototypes and improve the fabrication process to avoid cracking with future filter boxes. The local concrete vendor constructed and evaluated three prototypes: one with no reinforcement, another with chicken wire, and a third using thinner steel rebar reinforcement. All of the prototypes were deemed to be acceptable. The casting with 4 vertical steel bars located on the corners and 5 horizontal steel bars evenly spaced and skinnier than previous reinforcement worked the best. Eighteen biosand filters based on the third prototype were constructed in January 2013. They are expected to exhibit less cracking; however, time will tell. During that trip, the community pledged to repair cracks themselves. A list of repair steps is given in the Appendix.

\section{Project Setback - US Department of State Travel Warning}

The US State Department issued a travel warning for El Salvador in 2013. Rowan University does not let student clubs travel to countries with travel warnings. The club has been in touch with La Ceiba and is working to locate a chapter willing to take on the La Ceiba project, one unaffected by the travel warning.

\section{STUDENT OUTCOMES}

Students involved in EWB projects have the unique opportunity to gain a diverse skill set, which makes them a more viable and proficient candidate for potential employers. They learn about project and team management, trip planning, leadership, communication, fundraising, budgeting, and field work. In addition, students working on EWB projects learn about the culture that they are working in and develop a respect for that culture. Students take this cultural sensitivity and social responsibility outside of the confines of this project and act as advocates for impoverished communities. Students are asked to write a one-page reflection one each trip. Below are some excerpts from previous team members. 
"Even though our team had many first time travelers, I feel that we worked together efficiently, and finished all of our tasks right on schedule, if not earlier. I believe the greatest strength of our trip was the drive of our installation team to complete at least five installations a day, even if that meant working late into the night. This determination to complete our goals was a major reason why we were able to complete an ambitious schedule early." -John Gribbin, Junior Mechanical Engineering Major

"Before we left for our trip to El Salvador, I was pretty excited about the selected team that was traveling. Based on the team meetings before the trip, the team as a whole seemed to get along with each other very well. Some of us are very close friends; others are in the same class and major. As a whole, our team dynamic seemed to operate quite smoothly while we were in La Ceiba. We all got along and were able to complete all the tasks that were expected to be completed before the end of the trip. Along with our team's positive chemistry, I believe we were able to create an even stronger bond with the community of La Ceiba. As an individual team member, I tried my best in all the tasks that were expected of me to complete... I also tried to provide the team with comic relief whenever it was possible to make the labor of each day not seem so tiresome. I would like to think that it did in fact make the team's day easier. Throughout the entire trip, there were many positive aspects that resulted from it. As a team we worked very well together, completing all the team's responsibilities a day earlier than expected. Much of this can be explained by the overwhelming community help that we received in sieving and washing the components needed within each bio-sand filter. Because of this, we were able to spend the last day bonding with the community. We were able to interact with them on a recreational level rather than a business level. Playing with the community kids and interacting with their parents allowed the team to connect with the community on a personal level." - Cody Van Sciver, Junior Chemical Engineering Major

"During my time in La Ceiba the community really trusted and confided in me and told me personal and emotional stories they made me feel at home, one women even said to me "you have family in El Salvador." Because of their willingness to trust me so easily I found myself trusting in them as well as sharing my own stories. Experiencing the culture first hand allowed me to communicate with the town, educate them and become friends with them." - Rosa Metz, Junior Spanish Major

\section{Conclusions}

The ultimate goal of the Clean Water for La Ceiba project was to partner with the community to set in place a sustainable solution for providing clean drinking water. By staying with the project long-term, students exercised their social and civic responsibility while applying their engineering knowledge to a real-life problem.

Students at Rowan prepare for EWB projects by learning project skills in Freshman and Sophomore Engineering Clinic. Select EWB members work directly on EWB projects in their Junior and Senior Engineering Clinic. This results in a core of students able to work 6 to 10 hours a week on the EWB project. There is a synergy between rewarding student with course credit for working on EWB projects, and using EWB projects as a valuable context for teaching 
real world skills. Other students contribute to the EWB projects through student chapter activities.

The EWB students worked with the community to identify biosand filters as a sustainable way to provide safe drinking water. Working with a local concrete vender, the team modified a CAWST biosand filter design to work with the local conditions. The monitory program identified filter box cracking as an issue. Several prototypes were constructed and evaluated in country. One with thinner reinforcements was selected and used in La Ceiba starting in January 2013.

As of January 2013, 54 biosand filters have been constructed and installed in the community. Results indicate that filter recipients are satisfied their filters and able to maintain them. There is a notable self-reported decrease in water-related illness in the community. Water quality testing indicates that the biosand filters are producing water with little or no fecal coliform contamination.

The people of La Ceiba are good-hearted, hardworking people that deserve to enjoy necessities that are easily taken for granted. A US State Department travel ban in 2013 precluded Rowan EWB students from continuing to work with the community. The team remains in communication with the community and is working to find another chapter to help the community build more biosand filters.

\section{ACKNOWLEDGMENTS}

This project could not have been completed without the help of EWB-USA, Rowan Student Government Association, Rowan College of Engineering, Rowan Civil \& Environmental Engineering, Rowan EWB Student Chapter members and mentors, Yusuf Mehta, Kauser Jahan, Aaron Nolan, donors, and families of the team.

\section{REFERENCES}

${ }^{1}$ EWB (Engineers Without Borders - USA). (2013). Retrieved April 10, 2013, from http://www.ewb-usa.org.

${ }^{2}$ Everett, J., J. Newell, K. Dahm, J. Kadlowec, B. Sukumaran. (2004) Engineering Clinic: Bringing practice back into the engineering curriculum. Engineering Education Conference, University of Wolverhampton, England, UK.

${ }^{3}$ CIA - The World Factbook. (2013). Retrieved April 10, 2013, from https://www.cia.gov/library/publications/the-world-factbook/geos/es.html.

${ }^{4}$ Google Maps (2014) “El Salvador” maps.google.com, accessed 1/10/2014.

${ }^{5}$ Baals, A., Braun, C., Festa, P., Franchetti, R., Jimenez, R., Martensen, K., Muriel, K., Patel, T., Sacks, S., \& Tryner, J. (2007). 523 Alternatives Analysis. Rowan University EWB, Glassboro, NJ.

${ }^{6}$ CAWST. (2013). Retrieved April 10, 2013, from http://www.cawst.org. 
${ }^{7}$ CAWST (2009). Biosand Filter Manual: Design, Construction, Installation, Operation and Maintenance, CAWST, Calgary, Alberta, Canada.

${ }^{8}$ Barb, K., Booth, C., Burgin, B., Chapman, B., Hoffman, B., Schwalbenberg, P., \& Tryner, J. (2010a). 524 Preliminary Design Report. Rowan University EWB, Glassboro, NJ.

${ }^{9}$ Barb, K., Burgin, B., Chapman, B., Mondragon, A., Roche, J., Schwalbenberg, P., Tryner, J., \& Valentine, S. (2010b). 525 Pre-Implementation Report. Rowan University EWB, Glassboro, NJ.

${ }^{10}$ Barb, K., Cevallos, A., Gettings, S., Metz, R., Scaramazza, J., \& Van Sciver, C. (2012). 531 Post Monitoring Report. Rowan University EWB, Glassboro, NJ.

\section{Appendix}

\section{Biosand Filter construction}

Sieving: The sand has to be sieved into piles according to size, as the filter requires a very distinct configuration of sand. The sizes are identified as large gravel (1/4"), medium gravel $\left(1 / 8^{\prime \prime}\right)$, tiny gravel $\left(1 / 16^{\prime \prime}\right)$, and fine filtration sand $\left(<1 / 16^{\prime \prime}\right)$. Sand is imported from a quarry near the Capitol and has a mixture of all of these sizes. The mixture is scooped into a screen using a shovel and passed through by shaking the screen with either one or two people, with the remnants on the top of the screen placed in one pile and the remnants that passed through placed in another pile. Then the mix that passed through is shoveled into another sieve, etc, until all sand is separated by size. This is a time-consuming and tedious task, but the community helps with this task tremendously.

Washing: The sand has to be washed to remove dust and fine particles prior to installation. This is a "mechanical wash," since the sand is not actually being sanitized, just rinsed with river water. The community washes sand by the river using a system of buckets and a wheelbarrow. Sand has to be washed just enough so that it is not dusty, but not too clean so that bacteria cannot adsorb to it. A jar test is completed to check how turbid the sand will make the water when swirled, with the aim of achieving mid-level turbidity (not too dark, not too clear).

Lids: Lids are constructed out of wood and fit on the filter snugly. This ensures that large contaminants, as well as children and animals, do not enter the filter.

Diffusor plates: Diffusor plates are made out of aluminum plates, with holes drilled in a grid pattern. A small hook is attached so that the plate can be lifted out of the filter box for cleaning. Both the lids and diffusors plates have to be "custom made" because the filter boxes are all a little different in their sizing. 
Boxes have to be transported from the construction site to each recipient household, but this is no easy task. Some households are miles away, across rivers, up hills, and over rocky terrain. Filter boxes weigh about 200 pounds each. Therefore, transportation is a creative art in itself. In the past, the team has used trucks, wheelbarrows, and their bare hands to accomplish this task.

Once all of the materials are prepared, the filter is then ready to be implemented. A filter needs: 1 gallon $(3.79 \mathrm{~L})$ of $1 / 4$ " large gravel, $1 / 2$ gallon $(1.89 \mathrm{~L})$ of $1 / 8$ " medium gravel, $1 / 2$ gallon $(1.89 \mathrm{~L})$ of 1/16" tiny gravel, and 10 gallons $(37.85 \mathrm{~L})$ of fine filtration sand. After adding the sand, the filter must be flushed continuously until clear water leaves the outlet tube. The level of sand must then be adjusted so that there is a 2-inch standing water level.

After the filters are thoroughly flushed, they must then be disinfected to remove any contamination in the exit tube prior to use. This is done by pouring $5 \mathrm{~mL}$ of bleach into a $600 \mathrm{~mL}$ bottle and diluting it with water, then funneling the solution into the exit tube. Then the filter is flushed by pouring source water into the filter continuously until the water exits clear. After disinfection, the filter is ready to use, though maximum treatment is only achieved after the biological layer is established, which can take up to 30 days of continuous use.

\section{Cracking Repair Guidance}

- Hairline Cracks

1. Moisten the old concrete along the crack with water for several hours.

2. Add just enough water to cement to form a thick paste.

3. Make sure the old concrete is most but there is no water present.

4. After the crack has been moistened and cleaned add the thick paste formed in step 2 with a putty knife or pointing towel.

5. Force the paste into the crack as much as possible then smooth it off.

6. Allow the area to dry for around two hours then cover the area.

7. Keep the area covered for about five days lift the covering once each day to sprinkle with water.

- Deeper Cracks

1. Enlarge the crack with a cold chisel and hammer. Make it so that the crack is wider further into the concrete; make it so that the depth of this is around $1 / 4$ " inch.

2. Clean the area by using both a wire brush and water. Use a wire brush to remove all the present loose material on top of the crack and water to wash away loose material inside the crack.

3. Prime the area with a thin creamy mixture of cement and water. Allow two hours for this to dry.

4. Add water to the cement until it is the consistency of thick mud.

5. Moisten the area where the cement will be applied without leaving any water on the surface. 
6. Add mixed concrete to the area; force the mixture into cutaway areas with a pointing trowel. Be sure to use enough pressure to force the mix into all the areas of the crack.

7. Spread the patch over the old concrete to allow for a better bond between the old and new concrete.

8. Allow the patch to dry for two hours then cover.

9. Keep the concrete covered for the next five days removing the cover once a day in order to wet the area.

10. Fill any hairline cracks that form during the drying process.

- Holes

1. Remove any stray material located in the hole.

2. Cut the hole so that it is wider deeper in than at the surface.

3. Clean the hole with a brush and water to remove any stray material.

4. Apply a creamy mixture of cement and water, than wait for two hours.

5. Add water to the cement until it is the consistency of thick mud.

6. Moisten the area where the cement will be applied without leaving any water on the surface.

7. Then apply the cement mix in order to patch the hole with a pointing trowel.

8. Spread the patch over the old concrete to allow for a better bond between the old and new concrete.

9. Allow the patch top dry for two hours then cover.

10. Keep the concrete covered for the next five days removing the cover once a day in order to wet the area.

11. Fill any hairline cracks that form during the drying process. 


\section{Education Brochure}
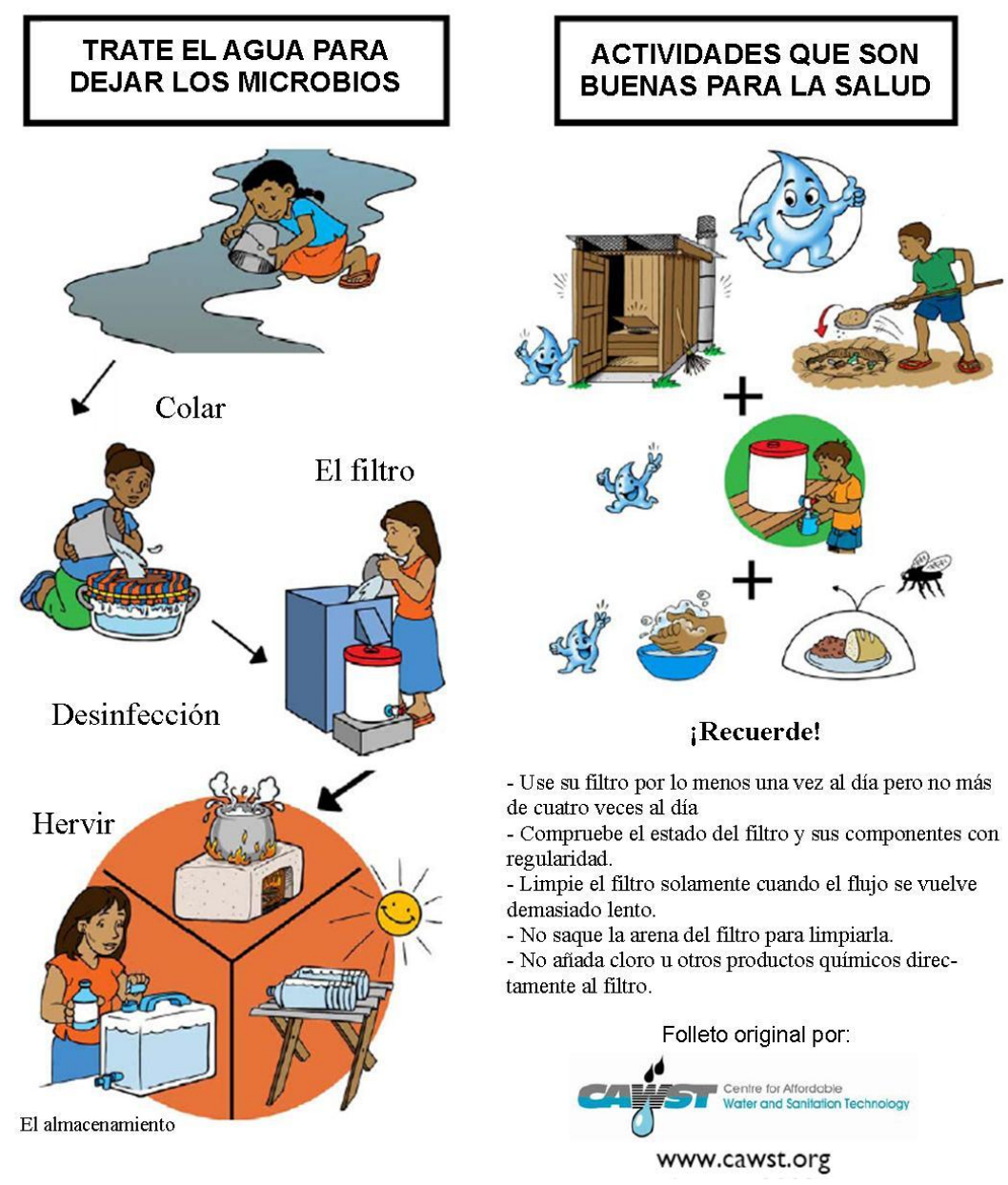

USE Y MANTENGA SU FILTRO

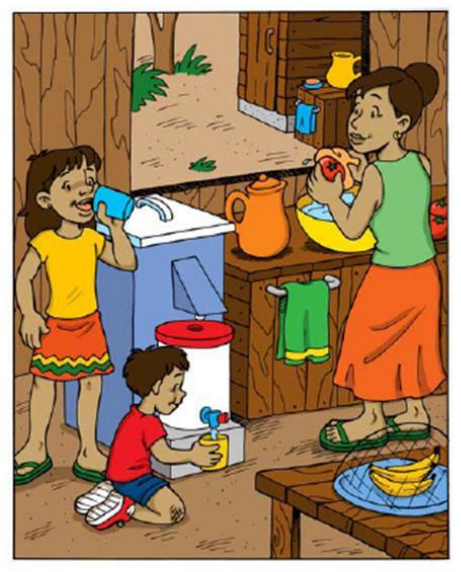

TENGA CUIDADO DE SU SALUD

TENGA CUIDADO DE SU FILTRO

ORowan University

Ingenieros Sin Fronteras www.rowan.edu/ewb 


\section{USE SU FILTRO}

Use su filtro por lo menos una vez al día pero no más de cuatro veces al día

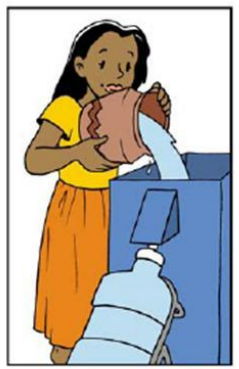

Paso 1 - Coloque un cubo limpio debajo

de la boquilla del filtro.

Paso 2 - Quite la tapa del filtro.

Paso 3 - Asegúrese que la placa de difusión está en su lugar. No vierta agua directamente sobre la arena.

Paso 4 - Eche cuidadosamente el agua en la parte superior del filtro.

Paso 5 - Permita que el agua drene completamente a través del filtro.

Paso 6 - Desinfecte el agua filtrada con cloro. Añada 2 gotas de PuriAgua por cada litro de agua. Deje reposar el agua por 30 minutos antes de tomarla.

Nota: PuriAgua no funciona treinta días después de su fabricación.

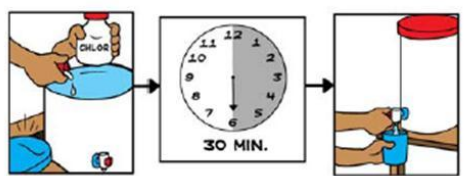

No añada cloro $u$ otros productos químicos directamente al filtro.

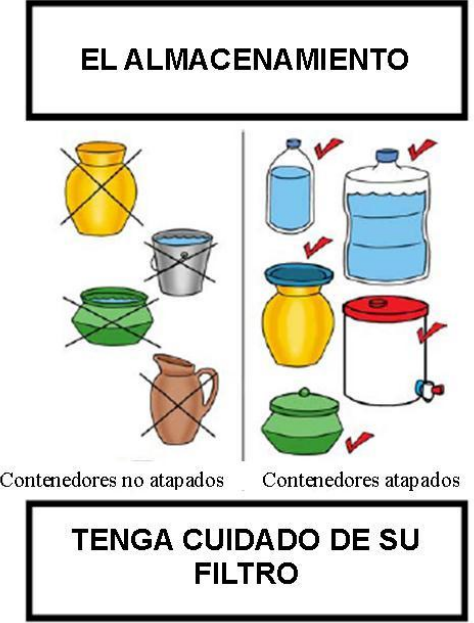

Limpie la tapa, placa de difusión, tubo de salida y el contenedor de almacenamiento regularmente con agua y jabón o una solución de cloro.
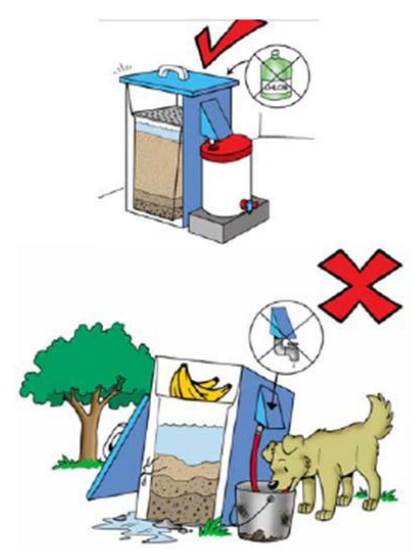

MANTENGA SU FILTRO

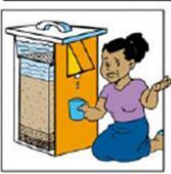

Meneando y agitando el agua es efectivo para la limpieza del filtro. Para usar este método siga las siguientes direc-

ciones:
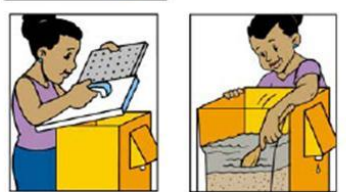

Paso 1 - Quite la tapa del fil-

Paso 2 - Si no hay agua en el difusor, ponga 4 litros (1 galón) de agua.

Paso 3 - Quite el difusor.

Usando la palma de la mano, suavemente toque el nivel de la arena y mueva su mano en

forma circular; con cuidado de no juntar la arena de arriba con la de abajo.

Paso 4 - Saque el agua sucia con el contenedor. Bote el agua en tierra o un jardín.

Paso 5 - Repita este método hasta que la velocidad del agua se halla recuperado.

Paso 6-Cambie el difusor y llene el filtro con agua.
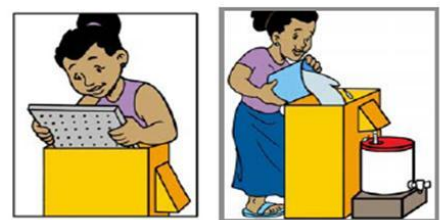

Nota: No saque la arena del filtro para limpiarla. 